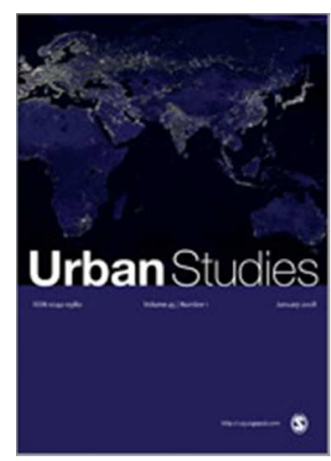

\title{
'Opening for business'? Neoliberalism and the cultural politics of modernising planning in Scotland
}

\begin{tabular}{|r|l|}
\hline Journal: & Urban Studies \\
\hline Manuscript ID & CUS-032-16-01.R1 \\
\hline $\begin{array}{r}\text { Manuscript Type: } \\
\text { keyword from the following list } \\
\text { that best describes the } \\
\text { discipline used in your paper.: }\end{array}$ & Planning \\
\hline $\begin{array}{r}\text { World Region: Please select } \\
\text { the region(s) that best reflect } \\
\text { the focus of your paper. } \\
\begin{array}{r}\text { Names of individual countries, } \\
\text { cities \& economic groupings } \\
\text { should appear in the title } \\
\text { where appropriate.: }\end{array}\end{array}$ & Europe \\
\hline $\begin{array}{r}\text { Major Topic: Please identify up } \\
\text { to two topics that best identify } \\
\text { the subject of your article.: }\end{array}$ & Governance, Built environment \\
\hline $\begin{array}{r}\text { Please supply a further } 5 \\
\text { relevant keywords in the fields } \\
\text { below:: }\end{array}$ & planning cultures, neoliberalism, planning reform, politics, Scotland \\
\hline
\end{tabular}

\section{SCHOLARONE \\ Manuscripts}




\title{
'Opening for business'? Neoliberalism and the cultural politics of modernising planning in Scotland
}

\begin{abstract}
In this paper I explore how the culture of land-use planning in Scotland has been targeted as an object of modernising reform, exploring how 'culture change' initiatives played a prominent role in stabilizing a new settlement around 'open for business' planning between 2006-12, containing potential tensions between diverse goals to make planning more efficient, inclusive and integrative. This highlights the potentially significant role of governance cultures in containing tensions and securing consent to processes of state restructuring. I therefore argue that greater empirical attentiveness to the cultural micro-politics of state restructuring can improve understanding of complex, contemporary dynamics of change, and the contested role of the neoliberal hegemonic project in reshaping urban governance. I conclude by arguing that the continued power of neoliberal critiques of the inefficiency of land-use planning indicate a need to acknowledge and engage contemporary cultural battles over the purposes of planning and urban governance.
\end{abstract}

Keywords: planning cultures, neoliberalism, planning reform, politics, Scotland

\section{Introduction: 'planning cultures' in neoliberal times?}

Attempts to reform urban planning systems and processes have become commonplace across many states, attesting to a pervasive view of planning as out of step with the requirements of 'modern' forms of government. The increasing frequency of such initiatives, and the negative rhetoric that often accompanies them, suggest a widespread loss of faith in the ability of state planning agencies to steer urban 
development in the public interest. Explanations of such reforms often suggest that planning ideas and practices have been under sustained ideological attack, subject to hostile processes of neoliberalisation (e.g. Lord and Tewdwr-Jones, 2014;

Allmendinger and Haughton, 2013).

The last forty years have undoubtedly seen a series of distinctive shifts in urban governance that have affected states and cities globally, albeit in highly differentiated ways: commitments to market mechanisms, the fostering of entrepreneurial values and inter-urban competition have become familiar planks of a new common-sense that has been widely if unevenly installed across diverse settings and sectors. In the global north this has been accompanied by sustained critique of images of the planned economy and 'failed' post-war state settlements that needed to be dismantled, justifying extended processes of regulatory restructuring, including planning reform. Yet, neoliberalism remains a contested keyword within contemporary urban scholarship where debate continues about its value as a meta-narrative of urban political transformation and its capacity to explain (and enable intervention in) complex processes of change (e.g. Blanco et al, 2014; Peck, 2013; Brenner et al, 2010; Barnett, 2010; Collier, 2012).

Particular concerns have been raised about the tendency for promiscuous use to present neoliberalism as a universal and monolithic force, inflating claims about its power, efficacy and coherence (Brenner et al, 2010; Peck, 2013). For critics, political economy interpretations subsume too much under the rubric 'neoliberal', thereby obscuring other significant vectors of social and political transformation (Barnett, 2009; Collier, 2012). Scholars committed to the necessity of neoliberalism as a descriptor for both broad historical tendencies and specific local transformations, stress its uneven and variegated nature, arguing for empirical analyses sensitive to 
contingent, contested and geographically diverse trajectories of neoliberalisation (e.g. Brenner et al, 2010; Peck, 2013). Notwithstanding certain conceptual tensions, such work has sought points of overlap between various distinct theoretical and methodological approaches to the study of neoliberalism, e.g. as hegemonic ideology, governmental rationality or policy regime (Larner, 2000; Peck, 2013; Newman, 2014).

An increasingly common stress has been placed on exploring neoliberalisation as a process rather than an accomplished project, requiring forms of analysis sensitive to the ways in which dominant discourses and rationalities interact with older residual, or newer emergent ideas and practices, unevenly provoking contestation, accommodation and evolving hybrid formations in different times and places (Clarke, 2008; Newman, 2014). This has led to calls for scholarship better attuned to the distinctive and complex ways in which various pressures for change, including neoliberal logics, come to be articulated together (Peck, 2013), moving beyond: "the failure of neoliberal narratives to grapple with the politics of how and why particular regimes emerge and become embedded across localities; and point[ing] to the possibility of alternative explanations that infuse accounts of neoliberalism with agency, politics, meaning and affect" (Blanco et al, 2014: 3130)

There are significant overlaps here, with recent interest in exploring 'planning cultures' (Sanyal, 2005). Indeed, the concept of planning culture has been framed in response to concerns that neoliberalism and globalisation are promoting homogenizing changes, prompting questions about the extent to which locally embedded cultures -bundles of planning ideas and practices- might variously enable local resistance or accommodation to global pressures for change (Sanyal, 2005). 
Questions about contemporary processes of planning reform, neoliberalization, and their impacts on planning cultures are given further significance in the context of the Global Financial Crisis (GFC) from 2007 onwards. Lovering (2010) points to the complicity of mainstream planning ideas and practices in the production of a crisis that developed from speculative bubbles in land and property, highlighting the importance of understanding of the status of planning cultures and the complex ways in which they are shaped and reshaped within contemporary regimes of spatial governance. That what looked like a profound crisis of neoliberalism came to be widely stabilised around a politics of public austerity heightens the need for such analysis. As yet, however, there has been little attempt to explicitly consider the effects of the GFC and the politics of putatively neoliberal reforms on planning cultures (though see Grange, 2014).

This paper seeks to address this gap by exploring the cultural politics of planning reform in Scotland, examining how two key discourses, 'modernisation' and 'culture change', targeted particular ideas and practices in order to shape a new settlement around the role and purpose of land-use planning in Scotland. Overall, I argue that this new settlement has been strongly disciplined by neoliberal and managerial logics, producing a particular, narrow definition of 'open for business' planning whose dominance was reinforced rather than undermined by the effects of crisis and austerity.

The paper therefore makes three key contributions: Firstly, it provides an empirical case study of the normalisation of neoliberal and managerial disciplines and their impact on cultures of urban planning and governance in post-GFC Scotland. Secondly, the paper highlights important limitations in existing research on i) planning cultures, that has not yet paid sufficient attention to the political (re)construction of planning 
ideas and practices, and ii) the neoliberalisation of planning ideas and practices, which has not yet paid sufficient attention to the cultural dimensions of politicalideological change. Thirdly, this leads me to argue more generally for greater attentiveness to cultural dimensions of state restructuring at micro-political levels where the state operates as a 'peopled process' (Peck, 2001); providing a means of understanding often overlooked dimensions of change, and generating insights into how broader hegemonic projects like neoliberalism reshape urban governance. In particular I suggest this focus illuminates how consent and resistance to such projects are actively produced and managed as part of the process of reshaping local regimes or settlements. Whilst this case highlights the significant role governance cultures can play in containing what Newman (2014) describes as the 'landscapes of antagonism' that characterise local governance, I end by also considering some possible resources from which resistance to further neoliberalizing reforms might be imagined.

\section{Politicising planning cultures, 'culturing' of the politics of planning}

Sanyal (2005) describes planning cultures as complex, emergent formations, constantly in flux they are shaped by a wide range of influences, including global and local politics. However, interest in planning cultures has tended to focus on the value and conceptual clarity of the concept for international comparative research and explaining planning practices in different national contexts (e.g. Othengrafen and Reimer, 2013; Taylor, 2014). Whilst usefully acknowledging the dynamics through which planning regimes are related to broader socio-political processes, this work has not been centrally concerned with understanding the cultural-political transformation of planning ideas and practices in recent decades. As a result it has tended to develop separately from accounts of the neoliberalisation of planning and urban governance. 
Drawing on wider debates from geography and urban studies, analyses of the neoliberalization of planning often posit the clear influence of neoliberal ideology, rationalities and policies but continue to debate the extent to which they have transformed planning ideas and practices (e.g. Lord and Tewdwr-Jones, 2014; Allmendinger and Haughton, 2013). Sager (2014) for example highlights the ways in which different ideological influences (neoliberalism, participatory democracy, environmentalism) may be coarticulated in urban plans, problematising any straightforward reading of neoliberal hegemony in planning practice. Whilst recognising that ideas of planning and neoliberalism are not mutually exclusive, Baeten (2012) highlights continued points of tension between neoliberal ideology and contemporary ideas of planning, suggesting the importance of remaining attentive to the complexity of ongoing processes of ideological change (and perhaps explaining the recent ubiquity of attempts to reform planning systems). As yet, however, studies of the neoliberalisation of planning have not foregrounded the cultural dimensions of such changes, i.e. whether and how neoliberal ideas have been accepted as a new ruling common-sense. For example, Sager's (2011) comprehensive review of neoliberalism and planning does not explicitly consider the political-cultural transformation of planning ideas and practices as a dimension of neoliberalisation.

The overlooking of cultural dimensions of state restructuring arguably reflects wider tendencies in accounts of neoliberalisation that often either present a largely 'unpeopled process' of systemic change or imply a pervasive power to produce compliant neoliberal subjects (Barnet, 2010). This has generated calls to explore the complex and uneven ways in which governance cultures are challenged and changed as various actors exercise agency within the 'fields of antagonism' generated by 
interactions between various governmental and political projects (Newman, 2014;

Blanco et al, 2014).

In this section of the paper I have established that: 1 . there is a need to (re)politicise research on planning cultures and 2. to fully understand the extent and nature of neoliberal hegemony there is a need to bring a cultural dimension to analysis of both planning reform and wider processes of state restructuring. In the section below I outline a set of conceptual tools to analyse the cultural politics of planning reform in Scotland.

\section{Approaching the cultural politics of planning in neoliberal times}

If neoliberalism remains a problematic concept, for present purposes I follow Hall (2011) in treating it as provisional if rather unsatisfactory shorthand for both a broad historical era (from the 1970s onwards), and the uneven roll-out in particular domains of a "political-cultural project that aims at transnational hegemony" (Clarke, 2008, 137, emphasis added); foregrounding the ways in which neoliberal discourses and rationalities interact with planning (or other) ideas and practices, unevenly provoking contestation, accommodation and new hybrid formations across different times and places.

If hegemony is understood as the tendency towards dominance of a bundle of ideas, producing consent to a ruling common-sense, it is also a process that must be actively constructed and reconstructed (Hall, 1988). Hegemonic projects seek to establish new settlements in which certain aspects of cultural formations (bundles of ideas, social relations, identities and material practices) are problematized whilst others are linked together, naturalised and depoliticised. Working to reshape a previously established settlement is always an uneven process, creating scope for various forms of co- 
optation and resistance (ibid). Hegemony is therefore also always an incomplete process, as a result, it is important to develop modes of critical analysis that are sensitive to challenges, tensions and fractures: the politics of neoliberalization (Clarke, 2008). It is also therefore important to pay attention to specific local practices, the sites where those politics are enacted; not assuming the presence of a stable pattern of domination but instead a series of locations where global strategies are being actively forged and potentially re-worked.

Since the field of government is typically contested, a space where various agendas struggle for influence, Newman (2014) and Clarke (2008) argue that analysis must remain attentive to the ways in which various governmental projects are assembled together. Thus whilst, dominant conceptions of state modernisation have been strongly shaped by neoliberal logics that promote, for example, the superiority of the private over the public, they have also been influenced by other more or less compatible logics. It is therefore crucial to develop modes of analysis that can trace the complex ways in which such logics are stitched together as part of processes of state restructuring.

Prevailing definitions of planning are always political-ideological constructs. The role and purpose of an activity like planning has historically been strongly influenced but not necessarily determined by powerful ideas about the nature and appropriate role of state intervention in society. These ideas shape particular rationalities about the best ways to govern, imposing particular forms of discipline that define what is considered acceptable and unacceptable. Some discourses, may attain particular power, what Peet (2002) terms hegemonic depth and extent through their wide circulation and regulatory force, becoming important determinants of a prevailing common-sense. 
Planning systems are typically charged with mediating society's contradictory desires for land-use, reconciling potential tensions between diverse goals, for example, to enable free-markets in land and property whilst ensuring that spatial development is subject to democratic control, does not damage valued environments, or can be steered to ensure positive social outcomes (Gunder, 2015). As a result they can be understood as potential ‘fields of antagonism' (Newman, 2014) where different governmental projects may co-exist, promoting competing conceptions of state intervention in spatial development.

In the rest of the paper I draw on these conceptual guidelines to analyse the reform of land-use planning in Scotland which has been presented as a necessary process of 'modernisation' for a system that was no longer 'fit for purpose'. In the sections that follow, I draw on a two-stage research project conducted in 2011-2012 that investigated how the 'culture' of planning in Scotland became a particular object of governmental attention as reforms were implemented from 2006 onwards.

The first stage involved interviews and documentary analysis conducted at the national level to understand how the 'modernisation' and 'culture change' agendas were framed, the key influences shaping them, and how key stakeholders understood the changes required. In total, twelve semi-structured interviews were conducted at this stage with representatives of the Scottish Government and its key agencies, planning professional and development industry bodies and environmental and community organisations.

Following this, a case study was conducted at local government level, examining the effects of modernisation and culture change on planning practices in the City of Edinburgh Council (CEC), chosen as an example of a local authority that positively 
embraced a 'culture change' in its approach to planning and development (CEC, 2008a) ${ }^{\mathrm{i}}$. At this stage a further fifteen interviews were conducted with: local authority planners working in both plan-making and development management; development professionals working in the city; elected officials; community organisations; and officers working in other council services (housing, regeneration, economic development). In addition documentary analysis of key council publications and local and national press reports were used as a means of further verifying and deepening the findings.

\section{Examining the discourses of modernisation and culture change}

Use of the discourse of 'modernisation' positions the planning reform agenda in Scotland as part of the wider reform of public administration that has characterised state restructuring in many locations in recent years. As Finlayson $(2003,67)$ argues, however, modernisation is a purely performative term that has no fixed real-world referent and only becomes meaningful through its articulation in particular concrete contexts. It packages change as a positive necessity, validating certain images of what modern government looks like. However, in doing so it also acts as a strategy of problematisation, contrasting a desirable future state with a status quo that needs to be reformed since it is somehow old-fashioned or out of step with the requirements of the modern world. Modernisation can therefore be understood as a key discursive stake in the reform of ideas of planning in Scotland, where the power to determine what constitutes 'modern planning' determines necessary change.

The importance of locally situated governance cultures to processes of state restructuring has been increasingly recognised by those who manage change programmes within the public sector through 'culture change' initiatives (Du Gay, 
2000; Hall, 2011). Mirroring developments in other places, it was widely claimed that a 'culture change' was required to achieve the goals of planning reform in Scotland, particularly amongst professional planners in the public sector (e.g. Scottish Government, 2005).

The discourse of culture change is drawn from theories of organisational change, part of the translation of private sector managerial practices into the public sector in recent decades. It is premised on the idea that successful organisations secure commitment to their goals by shaping a shared sense of purpose. In this regard the culture change that accompanied reform of the planning system in Scotland can be interpreted as an attempt to shape consent to the common-sense of a modernized planning system. Culture change therefore entails the definition of 'culture' as an object of governmental attention. As with the logic of modernisation, this involves the construction of a particular set of problems (the old planning culture), images of a desirable end state (the modern planning culture) and a series of mechanisms to generate the changes required. Whilst presented as a politically neutral managerial technology, culture change is perhaps better viewed as an extension of the politics of modernisation - a means of bringing the ideas, practices and identities of planners, particularly the public sector workforce, into line with the rationalities of 'modern planning'.

If the discourses of modernisation and culture change operate to redefine how different planning ideas and practices are constructed and understood, a key task for critical analysis is to explore how these stakes have been shaped and the extent to which they have succeeded in forging a new common-sense, securing commitment to new ways of thinking and acting. In the sections below I therefore 
go on to examine how modernisation and culture change came to be defined through the planning reform process in Scotland.

\section{Devolution, neoliberalisation and governance cultures in Scotland}

A failed independence referendum in September 2014, devolution and the reopening of a Scottish Parliament at Holyrood in 1999 have generated considerable debate about the extent to which patterns of governance change in Scotland have converged or diverged from a set of shared historical roots as part of the United Kingdom (UK) (e.g. Keating, 2005). It has been widely asserted that Scotland has a distinctive governance culture, relatively more corporatist, interventionist and politically pluralistic than the rest of the UK (Lloyd and Peel, 2009). However, this broad characterisation is contested, with critics arguing that a myth has grown up about Scotland's continued commitment to an interventionist public sector and welfare state.

Miller (2010), for example, argues that assertions of national distinctiveness have prevented effective analysis of the neoliberalisation of government and society in Scotland; drawing attention away from how successive 'modernising governments' in both Westminster and Holyrood have emphasised economic competitiveness as an overriding goal. This approach has continued under Scottish Nationalist Party (SNP) governments since 2007, where despite social democratic rhetoric, government policy has arguably deepened neoliberal commitments in key ways (e.g. through the pursuit of economic competitiveness and commitment to low corporation tax rates) (Davidson et al, 2016).

These debates highlight that the disarticulation of a previous social democratic settlement and its replacement by any putative neoliberal settlement remains a 
politically significant question in a devolved Scotland and provide some broad context within which to consider the cultural politics of planning reform.

\section{Landscapes of antagonism and the definition of a 'modern' planning culture}

In Scotland, planning reform began to be discussed before devolution and continues to the present, encompassing the first primary planning legislation passed by the Scottish parliament in 2006 (Lloyd and Peel, 2009, 110 contains a useful summary table of key events).

By comparison with successive waves of planning reform in England which have been marked by strong, negative rhetoric and repeated attempts to deal with a "broken system" (e.g. Inch, 2012), language in Scotland has generally been less strident, perhaps indicating a broader acceptance of the value of the planning system as a part of the governance landscape. However, the need for reform was also widely accepted:

The commitment to modernisation stemmed from a common perception...that the planning system is not serving Scotland well. (Scottish Government, 2005)

If reform reflected a view amongst a wide range of stakeholders that the system required change, how to interpret that change was nonetheless contested.

In the build up to the passing of new legislation three key justifications were presented for 'modernisation', each corresponding to key principles of wider public service and planning reform - efficiency, integration and inclusion - and responding to distinctive political pressures: 
1. Drawing on the hegemonic depth and weight of powerful neoliberal critiques of state planning, right-wing think tanks and the development industry had lobbied strongly that the key problem with the existing system was its inefficiency, lack of responsiveness to market pressures and overly-restrictive regulatory approach (e.g. McKay, 2004).

2. From within the public sector, including elements of the planning profession meanwhile, others argued that the planning system had become too inwardlooking and insufficiently responsive to the spatial needs of other government services. In response it needed to become a proactive force for strategic integration of the spatial impacts of public and private decision-makers.

3. Finally, community groups and environmental lobbies argued that the system was remote and unresponsive to wider democratic pressures. They therefore argued for a heightened commitment to the inclusion of wider publics in decision-making.

Efficiency, integration and inclusion therefore provided distinctive problematisations of the existing planning system and concrete images of what a modernised planning system and culture might look like. Each of these keywords, also however, potentially pointed towards different interpretations of modern planning, entailing the development of distinctive and potentially incompatible planning cultures, depending on how they were interpreted and combined together.

For example, neoliberal commitments to enabling free-markets are not necessarily incompatible with limited forms of tokenistic public participation to legitimate decisions with a veneer of inclusion. However, the aim of speeding up decisionmaking in the interests of economic efficiency is likely to work against more substantive commitments to participatory (and representative) democratic processes, 
potentially generating political tensions. The interpretation of these terms would therefore prove crucial to the shaping of a new settlement to govern planning's field of potential antagonisms.

\section{'Open for business' planning: towards a settlement around efficiency?}

Many of those interviewed recognised efficiency concerns as the primary driver of modernisation:

When we started the planning reform journey, our perception was that planning was seen as a barrier to development - full stop (National Civil Servant)

Driven by a strong critique of the cost and inefficiency of public-sector bureaucracies, the discourse of efficiency has been a key driver of reforms to public services and planning systems across the world ${ }^{\mathrm{ii}}$. Though the pursuit of efficiency is not necessarily neoliberal, it has been a key strategy of neoliberal problematisation that has arguably attained both hegemonic depth and extent (c.f. Gunder, 2015). Its logic suggests that making planning processes more efficient by reducing unnecessary 'redtape' will free the market to deliver the development on which sustainable economic growth relies (though, despite being consistently asserted, evidence that inefficiency is a major issue or that this strategy has led to more or better development is limited, see Adams and Watkins, 2014).

Scottish Governments have consistently sought to present themselves as "open for business" and have therefore been concerned to address perceived barriers to economic competitiveness. Increasingly well-organised development industry lobbies were therefore well-placed to raise concerns about the planning system: 
In the last few years we've established direct communication with... the Ministers who in the SNP understand how important planning is, also understand how important construction and house building is as a part of the economy... So we've gone from a position 10 or 15 years ago of being the outsider... seen as the enemy of the system, to being part of the fabric of how the system's run. (Development Industry Representative)

The efficiency of the planning system was given particular priority following the election of the first SNP minority administration in 2007 and the onset of the GFC. First Minister Alex Salmond's newly appointed Scottish Council of Economic Advisors devoted their first session to investigating planning as a potential blockage to the government's key priority of fostering "sustainable economic growth".

The long-standing equation of public sector practices with inefficiency and waste meant there were a range of managerial technologies available through which the problem of inefficiency could be addressed (arguably contrasting with a lack of tools for addressing the challenges of inclusion and integration). For example, planners and local authority managers were familiar with the idea that their work was a 'service' that needed to be responsive to the needs of its 'customers' and whose 'performance' could (and even should) be measured and rendered subject to disciplinary pressures for 'continuous improvement' in various ways, including, through attentiveness to performance targets that principally measured the speed of decision-making:

What it does do is, it puts pressure on us to perform. Again, personally I don't have a big problem with that. I think as with any kind of profession, we need to continue to improve our performance - as simple as that. Some of the figures we've got are pretty bad... I personally think we've got a five-year 
window to try and show that we actually can make that progress. (Planning Profession Representative)

As the quotation suggests, the discourse of efficiency assumed a powerful disciplinary role, intensified by a perception that the political status of planning in Scotland was fragile, under threat if not under attack.

A key symbol of the dominance of efficiency concerns as a means of proving that planning was 'open for business' was its effect on ideas of inclusion and integration. This was evident before the passing of legislation in 2006 when the then LabourLiberal Democrat coalition government chose not to introduce a third party right of appeal against the grant of planning permission as a means of strengthening the inclusion of affected publics in planning decision-making. The measure was strongly promoted by environmental lobbies (and backed by the SNP in opposition). The main reason cited for this decision was that extending appeal rights from developers to communities would be inefficient, empowering NIMBY opposition, slowing development and deterring private investment (a decision the SNP has backed in Government). This disciplinary effect was also evident in a tendency to view integration through the lens of efficiency, as a means of producing more proportionate and cost-effective regulation rather than as a potentially more ambitious commitment to integrate the spatial impacts of a wide-range of public and private service providers. In the next section below I go on to explore how the culture change agenda became a key mechanism for consolidating this settlement and containing potential tensions between divergent understandings of efficiency, integration and inclusion.

\section{'Culture change' and the making of 'open for business' planning}


Culture change became a prominent goal for the modernisation agenda once minds turned towards implementing the 2006 Act (e.g. Scottish Government, 2005), and was a particular emphasis as new regulations were being introduced:

[culture change] was very much a buzzword in 2006/2007, I think it's not quite as bad as it was, but yeah, it was...bandied around for all sorts of new bits and pieces (CEC Planning Policy Officer)

The dominance of efficiency concerns was apparent in the ways the culture change agenda was developed by the government. Of 34 action points identified in a 'Progress Report' on Delivering Planning Reform in March, 2010, thirty-two related to public sector practices (the other two were addressed to the private sector; no points were addressed to communities or non-governmental bodies). Around half related directly to identifiable efficiency goals like streamlining of process and speeding up of plans and decisions. The document therefore reinforced a view of culture change as being primarily concerned with the efficiency of public sector practices and particularly with those directly related to the speed of the development management process through which planning consents are granted:

So although there were other objectives...you look at the government's culture change page on their website...there are lots of touchy feely soft objectives in there... but it became quite a process driven operation... (Development industry representative)

However, 'open for business' planning was not a straightforward translation of development industry concerns for efficiency. This was evident in professional and governmental attempts to develop alternative ways of measuring the performance of 
planning, moving beyond a straightforward focus on speed to also consider quality of decision-making (HOPS, 2012). Notwithstanding a broad acceptance of managerial discipline, this suggested a continued level of resistance to the idea that planning was only a regulatory burden.

Following extensive discussion about the need for culture change, 'open for business' planning was interpreted and enacted within the public sector through a particular emphasis on developing improved collaborative relations with all stakeholders, but with a particular emphasis on the development industry. This was understood as an extension of the Scottish Government's approach to engaging stakeholders in the planning reform process (and arguably reflected longer-standing corporatist relations within the small and highly professionalised planning community in Scotland).

In practice, 'open for business' planning therefore meant a strong emphasis on improving communication to proactively facilitate development:

Do [planners] do things differently - yes I would say. On the whole I think people have embraced that and I think they do understand they need to deal with people in a different way, particularly to get out a message about being responsive to development, that we're not seen to be presenting a negative image. (CEC Planning manager)

Fostering a pro-development culture was understood by interviewees in both the local authority and private sector as a particular challenge in Edinburgh which, perhaps as a result of its strong economy and historic built environment, had a reputation as a difficult place to invest and develop:

Yeah I think the perception that, you know “Edinburgh's not open for 
business", that's one that we're always fighting and, you know, I think it's wrong...we would really like to change that but that's a real uphill struggle.

(CEC Development Management Officer)

The local authority's commitment to challenging this perception was symbolized by two key developments: First, the setting up of the Edinburgh Development Forum, a regular meeting of industry stakeholders to discuss issues of common concern, and; secondly, the Edinburgh Planning Concordat, a protocol for processing major development applications ${ }^{\mathrm{iii}}$ :

I would argue that the job has fundamentally changed, and certainly from my perspective there is far more outward engagement than we ever had before. So things like the Edinburgh Development Forum didn't exist before. We're engaging with the stakeholders and the development industry (CEC Planning Manager)

The development forum's done a bit of work on how Edinburgh's perceived by the development community in comparison to other cities, so they are aware of the need to present themselves as, you know "... we are up for business, we want you to come here and invest" (Planning Consultant)

The attempt to transform relations with the development industry through dialogue was therefore presented as a means of responding to concerns that planning was negative and reactive whilst also shaping a more positive role for public sector planners as enablers of development, retaining some commitment to inclusion of other stakeholders and better integrated development.

\section{'Open for business' planning as a new common-sense}


The commitment to 'facilitating development' was commonly contrasted with the problematic old culture it was replacing:
...some people saw themselves as what used to be called development control and there was I think a negative attitude. You were there to stop things happening if they weren't acceptable. You weren't necessarily able to say to people "Well look effectually if you'd come in and talked beforehand we could have worked out the best way through this" and you could in fact have taken a much more positive and enabling role... (CEC Development Management Officer)

Some planners felt that they had been working in this new way as "relationship managers" for some time. As a result one suggested that the culture change agenda, whilst welcome, was "a little bit insulting".

Others also expressed scepticism about the culture change agenda, however, the majority described new ways of working in positive terms, with many of those interviewed actively identifying with the principle of facilitating development in the name of sustainable economic growth:
And I think the notion of development has been a bit of a dirty word. That's actually what we're all here to do, is to manage the environment in which we're working. (National Agency Manager)

In this way, a broadly shared understanding of the aims of culture change seemed to have developed, a new common-sense, equated with the negotiated model of 'open for business' planning and entailing particular changes in the forms of knowledge, practices, relations and subject positions involved in professional planning (see table 
1). This was particularly strong in the public sector but was also acknowledged by the development industry. It was, however, accepted that progress towards the new culture remained uneven, with public sector managers admitting to pockets of resistance:

We've got a few dinosaurs... you know people who find it difficult to change and leave their old working practices behind (CEC Planning manager)

Development industry representatives, meanwhile, cautiously welcomed the direction of change but were clear that there remained "ailments of trust" between the public and private sectors. They argued that the public sector needed to go further in accepting market-defined "realities" and ensuring certainty of decision-making. The latter concern was sometimes related to political interference by obstructive, selfinterested publics or elected officials who needed to be trained to see planning decisions as 'quasi-judicial' rather than political choices.

\section{Economic crisis and 'open for business' planning}

It was widely accepted that the effects of the GFC had played an important role in shaping acceptance of the new 'open for business' planning culture, strengthening the equation of development activity with the public interest and creating opportunities to reshape relations between public authorities and the development industry. This was particularly true in Edinburgh, where the crisis had initially been interpreted as a serious threat to a city with a large concentration of financial services, leading to the production of an Economic Resilience Action Plan (ERAP) in 2008 (CEC, 2008b):

...we've linked with city development who have the [ERAP], really sort of Edinburgh's approach to the credit crunch [GFC], to say we want to be pro- 
delivery, we want jobs, we want economic activity... that [ERAP] that created a culture change almost. (Housing/Planning Project Officer)

The GFC had been interpreted as intensifying disciplinary pressures on the planning system to prove it could deliver on broader corporate commitments to growth (the five-year window of opportunity referred to above). However, it was also seen to have enabled new, more flexible practices. For example through the ERAP, CEC committed to negotiate with developers on sites stalled by the crisis to ensure the construction of affordable housing, using various national subsidies and other incentives to ensure construction of affordable units. By 2010/11 this approach had led to the construction of affordable housing exceeding private supply for the first time (CEC, 2011).

Both public and private sector actors agreed that the downturn in development activity had led to greater willingness amongst developers to accept a negotiated mode of "consensus planning". No-one was sure whether this would last if (or when) the market 'returned'. There were also concerns that this approach would prove difficult to resource in the event of an upturn in development. Perhaps ironically the negotiated model of 'open for business' planning, shaped as a response to concerns about the inefficiency and unresponsiveness of public sector planning, was not necessarily cost efficient for local planning authorities facing serious resource shortages as public sector austerity took hold:

The issue is...how...the delivery of that service is resourced and if you're going to engage with all the people... It's all very well changing your attitude and your culture and all the rest of it but it will only work if there is an adequate resourcing (CEC Development Management Offier) 


\section{Analysis: culture governance as a peaceful path to neoliberalisation?}

The modernisation of the land-use planning system in Scotland was framed as an attempt to address concerns related to efficiency, inclusion and integration. This highlights the extent to which the purpose and role of planning activity remains complex and contested, forming a potential 'landscape of antagonism' between alternative aspirations for planning (Newman, 2014).

Driven by the hegemonic depth and weight of neoliberal concerns that planning was acting as a barrier to economic growth, efficiency concerns assumed particular power in Scotland, both as a problematisation of existing planning practices and an articulation of the form that a modern planning culture should assume. This was reinforced by the ready availability of managerial techniques designed to discipline public sector practices. It was also notably strengthened by the ways the GFC had been interpreted, intensifying pressure to support development activity. The dominance of efficiency concerns also shaped the definition of goals associated with inclusion and integration.

The need for improved efficiency was partly recognised as an external threat, introducing pressures to perform. However, it was widely accepted within the planning professional community. Prevailing definitions of efficiency were subject to some subtle reworking as they were translated into 'open for business' planning, premised on enhancing collaboration between planning authorities and developers. This enabled public sector planners to claim a positive role as facilitators of development, a subject position many of those interviewed identified with. 
Extended discussion about the need for a new planning culture and explicit culture change mechanisms were important in securing acceptance of this new approach, which targeted and was more positively embraced in the public sector. Working on the grounds of preexisting corporatist governance relations, a dominant planning and governance culture therefore emerged that played a significant role in stabilising the meaning of modernisation, securing active consent to this new common-sense. This change was symbolised by the description of those planners who did not accept its terms as "dinosaurs" whose commitments and practices were problematically wedded to outmoded ways of working.

Modernisation therefore generated wide-spread acceptance of central tenets of a broadly neoliberal conception of market-supportive planning, with culture change helping secure a relatively peaceful path towards this new settlement around 'open for business' planning for sustainable economic growth. The story of modernisation and culture change in the land-use planning system in Scotland therefore suggests the importance of paying attention to the cultural dimensions of state restructuring processes, particularly when 'culture' itself becomes an object of governmental attention, mobilized to secure consent to 'peopled' processes of change.

The study also suggests the significant role locally situated (planning) cultures can play in managing potential antagonisms between different aspirations within the contested fields of local governance (cf. Newman, 2014). In this case potential tensions between different interpretations of efficiency, integration and inclusion were minimized, as dominant meanings were established and consolidated. 
It would, however, be misleading to argue that reform represented the wholesale neoliberalisation of planning in Scotland. Whilst there was broad acceptance that the public interest was now defined in terms of sustainable economic growth and that this was best achieved through better public sector understanding of the needs of the development industry, the ways in which 'open for business' planning was interpreted suggest some level of continued cultural resistance to any narrow interpretation of efficiency concerns. Albeit often in limited ways, goals of inclusion and integration also continued to be pursued. Light-touch, pro-growth planning had therefore become normalized, narrowing planners' 'acting space' (Grange, 2014) but not entirely displacing other concerns from the field, providing further evidence of the particular hybrid, trajectories that neoliberalisation takes in different places at different times (pace Brenner et al, 2010; Peck, 2013; Newman, 2014 etc).

The existence of "dinosaurs" within the planning profession also suggests the presence of residualised sub-cultures, potentially resistant to the new planning culture. One significant limitation of the work presented here is that it has focused more on dominant representations of the culture of planning, rather than examining how street-level actors may have resisted change in various ways. The presence of sub-cultures of resistance and, albeit limited, debate over the proper interpretation of efficiency, integration and inclusion potentially point towards alternative understandings of the role and purpose of planning in a modern Scotland, and therefore provide resources from which political challenges could be raised in the future. Any such challenges are unlikely to take the form of wholesale challenges to neoliberalism, but could instead coalesce around particular challenges to aspects of the post-2006 settlement and the ways in which 
it has framed Scotland's planning culture. Perhaps, for example, contesting claims that planning processes are inefficient by questioning the inefficient outcomes of market-led planning (Adams and Watkins, 2014). Or asserting the potential contribution of the planning system to governmental priorities other than the efficient pursuit of market-led growth, in Scotland this might include agendas around land reform, shaping healthy and sustainable places or community empowerment. These possibilities further highlight the value of thinking about change at micro-political levels as a means of challenging any tendency towards disempowering accounts of neoliberalism, restoring albeit modest possibilities for agency (Blanco et al, 2014).

In the meantime, however, the settlement around 'open for business' planning in Scotland seems itself to be under strain. The context created by the GFC arguably created the material conditions within which the negotiated model of development could become broadly accepted. However, subsequent cuts to local authority budgets and an upturn in development activity have destabilised this settlement. In a move that was widely interpreted as a response to the continued concerns of the housebuilding industry about the efficiency of decision-making, Alex Neill the government minister responsible announced a further "gamechanging" review of the planning system in Scotland in September 2015. It remains to be seen what the outcome of the review will be, however it seems likely the respondent who described a "5-year window" to prove planning could deliver may be proved prescient. The hegemonic depth and weight of the discourse of efficiency therefore continues to function as a powerful problematisation of planning ideas and practices, not just disciplining prevailing practices but also generating pressure for further cycles of neoliberalising reform. 


\section{Conclusions}

In this paper I have explored how the culture of land-use planning in Scotland was targeted as an object of governmental attention, shaping an unstable settlement around the idea of 'open for business' planning. In doing so I have suggested that planning and governance cultures can play a significant role in stabilising the 'fields of antagonism' that characterise contemporary local governance, potentially securing consent to neoliberalising change. The paper therefore highlights the importance of paying more detailed empirical attention to cultural dimensions of state restructuring at micro-political levels where the state operates as a 'peopled process' (Peck, 2001); providing a means of improving understanding of complex, contemporary dynamics of change and the contested role of various political projects, including neoliberalism, in reshaping urban governance. In particular I have suggested this illuminates how consent (and resistance) to such projects are actively produced and managed as part of the process of reshaping local regimes or settlements, highlighting the potential value of further research on the political-ideological reconstruction of planning and governance cultures as a means of deepening understanding of the depth and extent of neoliberal hegemony.

With planning ideas and practices continuing to be questioned across many states, this is a political as much as an academic imperative. Ultimately, if more positive ideas of planning and urban governance are to be shaped, even in neoliberal times, an essential starting point is to acknowledge that cultural battles are being waged and need to be actively engaged.

\section{Funding}




1
2
3
4
5
6
7
8
9
10
11
12
13
14
15
16
17
18
19
20
21
22
23
24
25
26
27
28
29
30
31
32
33
34
35
36
37
38
39
40
41
42
43
44
59
45
46
47
48
49
50
51
52
54
56

RICS Research Trust 433 


\section{References}

Adams, D. and Watkins, C. (2014) The Value of Planning, RTPI, London.

Allmendinger, P. and Haughton, G. (2013) The Evolution and Trajectories of English Spatial Governance: 'Neoliberal' Episodes in Planning, Planning Practice \& Research, 28(1), 6-26

Author (forthcoming) $X X X X X X X X X X X X X X$ - author will provide details

Baeten G (2012a) Neoliberal planning: Does it really exist? In: Taşan-Kok T and

Baeten G (eds) Contradictions of Neoliberal Planning. Berlin, Springer, 205-211.

Barnett, C. (2010) Publics and Markets: What's Wrong with Neoliberalism, In: Smith, S., Marston, S., Pain, R., Jones III , J. (eds) (2010) The Handbook of Social

Geography, London, Sage, 269-296

Blanco, Griggs, S. Sullivan, H. (2014) Situating the Local in the Neoliberalization and Transformation of Urban Governance, Urban Studies, 51(15), 3129-3146

Brenner, N., Peck, J., Theodore, N. (2010) After Neoliberalization?, Globalizations, 7 $3,327-345$

City of Edinburgh Council (CEC) (2008a) Culture Change in Planning, Planning Committee, 28 February, 2008.

CEC (2008b) Economic Resilience Action Plan, CEC, The City of Edinburgh Council, 16 October 2008

CEC (2011) City Housing Strategy 2012-2017, Health, Social Care and Housing Committee, 13 December 2011

Clarke, J. (2008). Living with/in and without neo-liberalism. Focaal, 51, 135-147.

Collier, S. J., 2012, Neoliberalism as big Leviathan, or...? A response to Wacquant 
and Hilgers. Social Anthropology, 20, 186-195.

du Gay, P. (2000) In Praise of Bureaucracy, London, Sage.

Davidson, N., Virdee, S, Morrison, J, Mooney, G. (2016) Scotland and Alternatives to Neoliberalism, Soundings, 63,55-72

Finlayson, A. (2003) Making Sense of New Labour, London, Lawrence and Wishart.

Grange, K. (2014) In search of radical democracy: The ideological character of current political advocacies for culture change in planning, Environment and Planning A, 46, 2670-2685

Gunder, M. (2015) Planning's "Failure” to Ensure Efficient Market Delivery: A Lacanian Deconstruction of this Neoliberal Scapegoating Fantasy, European Planning Studies, 1-18 DOI:10.1080/09654313.2015.1067291.

Hall, S. (1988) The toad in the garden: Thatcherism among the theorists, in: C. Nelson \& L. Grossberg (Eds) Marxism and the Interpretation of Culture, Chicago, University of Illinois Press, 58-74

Hall, S. (2011) The Neoliberal Revolution, Cultural Studies, 25(6), 705-28

Heads of Planning Scotland (2012) Planning Performance Framework: http://www.hopscotland.org.uk/images/stories/Reports/hops\%20planning\%20perform ance\%20framework.pdf accessed 1/10/12

Inch, A. (2012b) Creating 'a generation of NIMBYs'? Interpreting the role of the state in managing the politics of urban development, Environment and Planning $C$ : Government and Policy 30(3) 520 - 535

Keating, M. (2005) Policy Divergance and Convergance in Scotland under Devolution, Regional Studies, 39(4), 453-463. 
Lord, A. and Tewdwr-Jones,M. (2014) Is Planning 'under Attack'? Chronicling the deregulation of urban and Environmental Planning in England, European Planning Studies, 22 (2), 345-361

Lovering, J. (2009) The recession and the end of planning as we have known it, International Planning Studies, 14(1), 1-6

Lloyd, G and Peel, D. (2009) New Labour and the Planning System in Scotland: An Overview of a Decade, Planning Practice and Research, 24 (1), 103-118

Lloyd, M.G. and Peel, D. (2012) Soft contractualism? Facilitating institutional change in planning and development relations in Scotland, Urban Research \& Practice, 5(2), 239-255.

MacKay, D. (2004) The Planning Famine: Reforming Land Use Planning in Scotland, The Policy Institute, Series: Economy No. 8 November, Edinburgh.

Miller, D. (2010) Who Rules Scotland? Neoliberalism, the Scottish Ruling Class and its Intellectuals, In: Davidson,N., McCafferty, P. and Miller, D. (eds.) Neoliberal Scotland: class and society in a stateless nation, Cambridge, Cambridge Scholars, 93-136.

Newman, J. (2014) Landscapes of Antagonism: Local Governance, Neoliberalism and Austerity, Urban Studies, 51(15), 3290-3305

Othengrafen, F. and Reimer, S. (2013) The embeddedness of planning in cultural contexts: theoretical foundations for the analysis of dynamics planning cultures, Environment and Planning A, 45, 1269-1284. 
Peck, J. (2001) Neoliberalizing States: Thin Policies/Hard Outcomes, Progress in Human Geography, 25(3), 445-455

Peck, J. (2013) Explaining (with) Neoliberalism, Territory, Politics, Governance $1(2), 132-157$

Peet, R. (2002) Ideology, Discourse and the Geography of Hegemony: From socialist to neoliberal development in post-apartheid South Africa, Antipode, 34(1), 54-84

Sager, T. (2011) Neo-liberal urban planning policies: A literature survey 1990-2010. Progress in Planning 76(4): 147-199.

Sager, T. (2014) Ideological Traces in Plans for Compact Cities: Is Neoliberalism Hegemonic? Planning Theory, DOI:10.1177/1473095214527279, 1-28

Sanyal, B. (2005) Hybrid Planning Cultures: the search for the global planning commons. In: Sanyal, B. (ed) Comparative Planning Cultures, Abingdon, Taylor and Francis, 3-25

Scottish Government (2005) Modernising the Planning System: A White Paper, Edinburgh, Scottish Government.

Scottish Government (2010) Delivering Planning Reform: Progress Report, Edinburgh, Scottish Government.

Taylor, Z. (2013) Rethinking Planning Culture: A New Institutionalist Approach, Town Planning Review, 84(6), 683-702. 


\section{Notes}

${ }^{\text {i }} \mathrm{CEC}$ is the local authority responsible for Scotland's capital city. The total population of Edinburgh was 486,120 in 2010, with growth rates outstripping the rest of the country over the previous three decades. Growth was premised on a strong economy, with concentrations in financial services, higher education, and public services (including the Scottish Government) as well as tourism drawn to the city's historic built environment. At the time the research was conducted in 2012 the Council was led by a Labour - SNP coalition. Despite changes in political control, and the politicisation of certain issues, there remained a reasonably stable settlement over key priorities, particularly the need to pursue a strategy of economic growth.

ii This section of the paper draws on Author, forthcoming

iii The Forum was set up to improve relations between CEC and key stakeholders, particularly the development industry. Meeting quarterly, it led to efforts to develop a shared evidence base about development needs in the city The concordat emerged from the Forum as an agreed process for managing major development proposals, particularly through processing agreements intended to give developers certainty about decision-making timescales (see Lloyd and Peel, 2012). 


\begin{tabular}{|c|c|c|}
\hline $\begin{array}{l}\text { Element of } \\
\text { planning culture }\end{array}$ & $\begin{array}{l}\text { Old system culture } \\
\text { (pre-2006) }\end{array}$ & $\begin{array}{l}\text { 'Modern' system } \\
\text { culture (post-2006) }\end{array}$ \\
\hline $\begin{array}{l}\text { Knowledges and } \\
\text { practices }\end{array}$ & $\begin{array}{l}\text { Knowledge of } \\
\text { statutory system. } \\
\text { Bureaucratic processes } \\
\text { and practices. Limited } \\
\text { engagement with other } \\
\text { stakeholders }\end{array}$ & $\begin{array}{l}\text { Knowledge of how to } \\
\text { use statutory system to } \\
\text { make facilitate } \\
\text { development. } \\
\text { Emphasis on improved } \\
\text { project management/ } \\
\text { knowledge of } \\
\text { development } \\
\text { economics }\end{array}$ \\
\hline Relations of practice & $\begin{array}{l}\text { Formal and } \\
\text { bureaucratic, remote, } \\
\text { quasi-legal }\end{array}$ & $\begin{array}{l}\text { Outward looking, } \\
\text { engagement with all } \\
\text { stakeholders, willing } \\
\text { to negotiate }\end{array}$ \\
\hline $\begin{array}{l}\text { Roles and identities for } \\
\text { public sector planners }\end{array}$ & $\begin{array}{l}\text { Bureaucratic, } \\
\text { regulator, inhibitor of } \\
\text { development, guardian } \\
\text { of public interest by } \\
\text { regulating private } \\
\text { sector }\end{array}$ & $\begin{array}{l}\text { Dynamic facilitator of } \\
\text { development; } \\
\text { proactive seeking } \\
\text { solutions; guardian of } \\
\text { public interest defined } \\
\text { by collaboration with } \\
\text { private sector }\end{array}$ \\
\hline
\end{tabular}

